\title{
Como Avançar na Humanização do Cuidado Oferecido por uma Unidade Básica de Saúde? Uma Pesquisa Implicada
}

\author{
Molina, Marcia Castagna \\ Prefeitura Municipal de Campinas — marciacastagnamolina@gmail.com
}

INTRODUÇÃO o estudo relata uma pesquisa-intervenção em uma Unidade Básica de Saúde, onde atuo como apoiadora distrital, compondo minha defesa de doutorado. o empírico da tese começou com um pedido para que eu trabalhasse a "comunicação" na equipe. a intervenção cumpriu duas etapas. na primeira, foram realizadas as "oficinas de comunicação", envolvendo os funcionários da unidade, mantendo encontros durante os seis meses seguintes. a segunda etapa constituiu-se de "oficina de humanização", preparada a partir de entrevistas com os trabalhadores, sobre seu entendimento a respeito da humanização e sobre o cuidado oferecido pela unidade de saúde. OBJETIVOS Desenvolver pesquisa-intervenção em UBS, construindo reflexões e ações voltadas para humanização das relações. Compreender a dinâmica das relações que ocorrem na UBS e identificar entraves ao aprimoramento do cuidado oferecido. Construir, em conjunto com a equipe, intervenções para o aprimoramento do cuidado. MÉTODOS o desafio metodológico foi transitar da função institucional que exerço a partir de marcado lugar de poder, autoridade e de "exterioridade" em relação à equipe de trabalhadores, para uma inserção mais íntima e "interna" às suas relações micropolíticas, tentando produzir, com eles, reflexões e ações voltadas para a humanização das relações que regem seu cotidiano e, ao mesmo tempo, das relações que estabelecem com os usuários na produção do cuidado. uma pesquisa implicada, portanto, porque tive que lidar o tempo todo, com a tensa relação entre minha localização na hierarquia das relações, com a dinâmica e modo de funcionamentos da equipe. o estudo apresenta e problematiza o movimento de interiorização/exteriorização em relação ao campo micropolítico que foi sendo investigado, modificado e produzido. uma intervenção que produzisse, ao mesmo tempo, o "objeto" e a teoria para pensar o "objeto" que estava sendo produzido. RESULTADOS Os parâmetros utilizados nas discussões foram os de respeito à vida e à dignidade das pessoas, conforme a Política Nacional de Humanização $(\mathrm{PNH})$ do Ministério da Saúde. como decorrência foi implantado novo acolhimento na UBS, com escuta qualificada dos usuários, consulta ao prontuário, retaguarda de enfermeira e de médico aos auxiliares de enfermagem. Mudança que gerou maior integralidade e equidade aos atendimentos, mas trouxe também desacomodação da equipe e novos conflitos a serem gerenciados. CONCLUSÃO Este trabalho constitui-se em reflexões geradas pelos encontros vivenciados no doutorado com usuários, trabalhadores, gestores, autores e orientador. a pesquisa possibilitou aproximação com a PNH que conclama a delicadeza da escuta, o envolvimento e a prática do cuidado. Valoriza a expansão, criatividade, escolhas necessárias em uma UBS, o que dificilmente se pode esperar de trabalhadores enquadrados em protocolos prontos. um dos maiores aprendizados do processo é que o cuidado se dá em rede, sua produção e recriação permanentes devem ser trabalho constante da gestão.

Molina, Marcia Castagna. Como Avançar na Humanização do Cuidado Oferecido por uma Unidade Básica de Saúde? uma Pesquisa Implicada. In: Anais do Congresso Internacional de Humanidades \& Humanização em Saúde [= Blucher Medical Proceedings, num.2, vol.1]. São Paulo: Editora Blucher, 2014. ISSN 2357-7282

DOI 10.5151/medpro-cihhs-10404 